Original Research Article

\title{
Beneficial role of Avocado oil orally used in Osteoarthritis: experience in a tertiary care hospital of Bihar, India
}

\author{
Akash Chandra', Anjani Kumar², Manish Kumar ${ }^{3 *}$, Manish Kumar ${ }^{1}$, Harihar Dikshit ${ }^{1}$
}

\begin{abstract}
${ }^{1}$ Department of Pharmacology, ${ }^{2}$ Department of Medicine, ${ }^{3}$ Department of Orthopedics, Indira Gandhi Institute of Medical Sciences, Sheikhpura, Patna, India
\end{abstract}

Received: 10 January 2019

Revised: 01 May 2019

Accepted: 07 May 2019

*Correspondence to:

Dr. Manish Kumar,

Email: manishorthomicro@ gmail.com

Copyright: (C) the author(s), publisher and licensee Medip Academy. This is an openaccess article distributed under the terms of the Creative Commons Attribution NonCommercial License, which permits unrestricted noncommercial use, distribution, and reproduction in any medium, provided the original work is properly cited.

\begin{abstract}
Background: Osteoarthritis is the most common type of joint disease. It represents a heterogeneous group of conditions resulting in common histopathologic and radiologic changes. It is a degenerative disorder arising from biochemical breakdown of articular (hyaline) cartilage in the synovial joints.

Methods: Total of 90 patients were randomly selected from outdoor and indoor of Orthopaedics department (IGIMS Patna). Study was done in Department of Pharmacology \& Orthopaedics at IGIMS Patna. Three groups A, B and C were taken. Each group was consist of 30 patients of both sexes and age groups between 18 to 65 years. Group A was received Multivitamin with Exercise. Group B was received NSAIDS only. Group C was received Avocado oil orally along with Exercises as Muscle strengthening exercises of Quadriceps, Hamstrings, Abductor and Adductor muscles of thigh. We had compared pain thresholds among all these three groups with the help of Visual analogue scale and Oxford Knee score.

Results: After 3 months of treatment the patients belonging to group $\mathrm{C}$ showed better response as compared to group $\mathrm{A}$ and $\mathrm{B}$. When we compared pain threshold among group A, B and C on the basis of Oxford Knee score group C had occupied maximum score, which meant satisfactory joint functions and did not require any formal treatment. we also compared average visual analogue scale and average oxford knee score, Group C showed better response.

Conclusions: Avocado oil is a food supplement and does not contain any side effects as compared to NSAIDS [Non-steroidal anti inflammatory drugs], glucosamine sulfate, chondroitin sulfate, sulfasalazine etc so avocado oil can be used for long duration in case of osteoarthritis.
\end{abstract}

Keywords: Avocado oil, NSAIDS, Osteoarthritis, Oxford Knee score, Synovial joints, Visual analogue scale

\section{INTRODUCTION}

Osteoarthritis is a chronic joint disease characterized by pain and stiffness. ${ }^{1}$ It most commonly affects the weightbearing joints like the knees and hips. The disease is characterized by its progressive nature, specially damage of articular cartilage, boneremodeling, new bone formation, synovial inflammation, and fibrosis. In smaller joints, such as at the fingers, hard bony enlargements, called Heberden's nodes (on the distal interphalangeal joints) or Bouchard's nodes (on the proximal interphalangeal joints) occurs due to osteoarthritis. Causes include previous joint injury, abnormal joint or limb development and inherited factors. ${ }^{2}$ Due to osteoarthritis there is breakdown of articular cartilage and underlying bone. ${ }^{3}$ Articular cartilage is the smooth coating that covers the surface of the bones inside a joint. Articular cartilage also cushions and helps lubricate the joint surfaces. Over 
time the articular cartilage can thin or form cracks. Pieces of articular cartilage may become loose and float inside the joint and further irritate the joint. After a long period of time the articular cartilage can become completely "worn away" and the bones can rub together. Osteoarthritis usually comes on slowly and results in joint pain stiffness and swelling. Sometimes a grating sound can be heard when a joint is moved such as the knee when going up or down stairs.

Some risk factors for Osteoarthritis include:

- $\quad$ Previous joint injury.

- Family history of Osteoarthritis.

- Damage to the joint from other types of arthritis.

- Increasing age.

- Being overweight (affects mainly weight bearing joints).

\section{Treatment}

Lifestyle modification (such as weight loss and exercise) and analgesics are the mainstays of treatment. Acetaminophen (also known as paracetamol) is recommended first line NSAIDS being used add on therapy only if pain relief is not sufficient. ${ }^{4}$

\section{METHODS}

The aims and objectives were to compare the efficacy of NSAIDs and AVOCADO OIL over pain threshold in case of osteoarthritis along with following objectives as:

- Comparative pain overcoming effects of NSAIDs and AVOCADO OIL along with exercise.

- $\quad$ Endurance of patient's day to day physical activities.

- Pain improvement during squatting position.

- $\quad$ Patient's sense of well being.

Total 90 patients were randomly selected from outdoor and indoor of Orthopaedics department. Study was done in Department of Pharmacology and Orthopaedics at IGIMS, Patna. Total three groups as A, B and C were taken. Each group consisted of 30 patients of both sexes and variable age groups between 18 to 65 years. Group A received Multivitamin with Exercise. Group B received NSAIDs. Group $\mathrm{C}$ received Avocado oil orally along with Exercise. Muscle strengthening exercises of Quadriceps, Hamstrings, Abductor and Adductor muscles of thigh was carried out. Wefollowed up the patients of all groups at OPD after 6weeks and 3months and compared the effects and pain threshold by Oxford knee score and Visual analogue score. The Oxford Knee Score has subsequently been validated for use in assessing other non-surgical therapies applied to those suffering from issues with the knee. ${ }^{5}$ Visual analogue scales have superior metrical characteristics than discrete scales, thus a wider range of statistical methods can be applied to the measurements. ${ }^{6}$ Tablet paracetamol $650 \mathrm{mg}$ twice daily was used as NSAID in patients of Group B, Soft gelatin capsule of avocado oil [300 mg] once daily was used in patients of Group C. In case of acute pain emergency tablet Ibuprofen $400 \mathrm{mg}$ was used as rescue medicine in case of patients belonging to Group C and Group A.

Study period was 3 months. It was prospective and interventional study.

\section{Inclusion criteria}

- Clinically and Radiologically diagnosed Osteoarthritis grade I and II

- Post traumatic arthritis

\section{Exclusion criteria}

- $\quad$ Arthritis due to connective tissue disorder.

- Patient age below 18 years and above 65 years.

- Non specific knee pain

\section{Initial investigations}

- $\quad$ Plain x-ray,Body mass index (BMI),Body weight

- Measurement of pain threshold

Following tests were performed to measure pain threshold.

- $\quad$ Oxford knee score

- Visual Analogue Scale

\section{Average results from 90 patients}

Group C has achieved better pain threshold score as comparison to Group A \& Group B. Group B has occupied Average Visual Analogue scale of 3.37 and the Average oxford knee score of 40.20 , but patients still complaining of mild pain and mild stiffness of joints, while patients have no any complain in Group $\mathrm{C}$ after enrollment of three months. The above data shows that patients receiving avocado oil have achieved better pain overcoming and anti inflammatory effects as compare to patients who are receiving Multivitamins with exercises \& NSAIDS only. Avocado oil also showing better response towards joint stiffness among patients as compare to patients who receiving NSAIDS only and Multivitamins with exercises. Afer enrollment of 3 months patients have no any complain regarding joint stiffness when they are receiving Avocado oil.

Has achieved average Visual Analogue scale of 5.63 after enrollment of three months and achieved average oxford knee score of 19.80 after enrollment of three months (Table 1). Has achieved average Visual Analogue scale of 3.37 after enrollment of three months \& achieved average oxford knee score of 40.20 after enrollment of three months (Table 2). Has achieved average Visual Analogue scale of 2.27 after enrollment of three months and achieved average oxford knee score of 42.10 after enrollment of three months (Table 3). 
Table 1: Group A- patients receiving multivitamins with exercises.

\begin{tabular}{|c|c|c|c|c|c|c|c|c|c|c|c|}
\hline \multirow[t]{2}{*}{ Group- A } & & & \multicolumn{3}{|c|}{ At the time of enrollment } & \multicolumn{3}{|c|}{ At 6 weeks } & \multicolumn{3}{|c|}{ At 3 months } \\
\hline & $\begin{array}{l}\text { Group } \\
\text { of } \\
\text { patients }\end{array}$ & $\begin{array}{l}\text { Average } \\
\text { Age/ sex }\end{array}$ & $\begin{array}{l}\text { Clinical } \\
\text { features }\end{array}$ & $\begin{array}{l}\text { Visual } \\
\text { analogue } \\
\text { scale }\end{array}$ & $\begin{array}{l}\text { Oxford } \\
\text { knee } \\
\text { score }\end{array}$ & $\begin{array}{l}\text { Clinical } \\
\text { features }\end{array}$ & $\begin{array}{l}\text { Visual } \\
\text { analogue } \\
\text { scale }\end{array}$ & $\begin{array}{l}\text { Oxford } \\
\text { knee } \\
\text { score }\end{array}$ & $\begin{array}{l}\text { Clinical } \\
\text { features }\end{array}$ & $\begin{array}{l}\text { Visual } \\
\text { analogue } \\
\text { scale }\end{array}$ & $\begin{array}{l}\text { Oxford } \\
\text { knee } \\
\text { score }\end{array}$ \\
\hline $\begin{array}{l}\text { Average } \\
\text { results }\end{array}$ & 30 & 36.87 & $\begin{array}{l}\text { Pain, } \\
\text { swelling, } \\
\text { stiffness at } \\
\text { different } \\
\text { body } \\
\text { Parts/joints }\end{array}$ & 7.93 & 15.50 & $\begin{array}{l}\text { Pain, } \\
\text { swelling, } \\
\text { stiffness } \\
\text { at } \\
\text { different } \\
\text { body } \\
\text { Parts/ } \\
\text { joints }\end{array}$ & 6.80 & 17.10 & $\begin{array}{l}\text { Pain, } \\
\text { swelling, } \\
\text { stiffness } \\
\text { at } \\
\text { different } \\
\text { body } \\
\text { Parts/ } \\
\text { joints }\end{array}$ & 5.63 & 19.80 \\
\hline
\end{tabular}

Table 2: Group B- patients receiving nsaids only.

\begin{tabular}{|c|c|c|c|c|c|c|c|c|c|c|c|}
\hline \multirow[t]{2}{*}{ Group- A } & \multicolumn{5}{|c|}{ At the time of enrollment } & \multicolumn{3}{|c|}{ At 6 weeks } & \multicolumn{3}{|c|}{ At 3 months } \\
\hline & $\begin{array}{l}\text { Group } \\
\text { of } \\
\text { patients }\end{array}$ & $\begin{array}{l}\text { Average } \\
\text { Age/ sex }\end{array}$ & $\begin{array}{l}\text { Clinical } \\
\text { features }\end{array}$ & $\begin{array}{l}\text { Visual } \\
\text { analogue } \\
\text { scale }\end{array}$ & $\begin{array}{l}\text { Oxford } \\
\text { knee } \\
\text { score }\end{array}$ & $\begin{array}{l}\text { Clinical } \\
\text { features }\end{array}$ & $\begin{array}{l}\text { Visual } \\
\text { analogue } \\
\text { scale }\end{array}$ & $\begin{array}{l}\text { Oxford } \\
\text { knee } \\
\text { score }\end{array}$ & $\begin{array}{l}\text { Clinical } \\
\text { features }\end{array}$ & $\begin{array}{l}\text { Visual } \\
\text { analogue } \\
\text { scale }\end{array}$ & $\begin{array}{l}\text { Oxford } \\
\text { knee } \\
\text { score }\end{array}$ \\
\hline $\begin{array}{l}\text { Average } \\
\text { results }\end{array}$ & 30 & 37.47 & $\begin{array}{l}\text { Pain, } \\
\text { swelling, } \\
\text { stiffness at } \\
\text { different } \\
\text { body } \\
\text { Parts/joints }\end{array}$ & 5.57 & 26.13 & $\begin{array}{l}\text { Mild } \\
\text { pain, } \\
\text { swelling, } \\
\text { stiffness } \\
\text { at } \\
\text { different } \\
\text { body } \\
\text { Parts/ } \\
\text { joints }\end{array}$ & 4.33 & 35.90 & $\begin{array}{l}\text { Mild } \\
\text { pain and } \\
\text { stiffness } \\
\text { at } \\
\text { different } \\
\text { body } \\
\text { Parts/ } \\
\text { joints }\end{array}$ & 3.37 & 40.20 \\
\hline
\end{tabular}

Table 3: Group C- patients receiving avocado oil with exercises.

\begin{tabular}{|c|c|c|c|c|c|c|c|c|c|c|c|}
\hline \multirow[t]{2}{*}{ Group- A } & & & \multicolumn{3}{|c|}{ At the time of enrollment } & \multicolumn{3}{|c|}{ At 6 weeks } & \multicolumn{3}{|c|}{ At 3 months } \\
\hline & $\begin{array}{l}\text { Group } \\
\text { of } \\
\text { patients }\end{array}$ & $\begin{array}{l}\text { Average } \\
\text { Age/ sex }\end{array}$ & $\begin{array}{l}\text { Clinical } \\
\text { features }\end{array}$ & $\begin{array}{l}\text { Visual } \\
\text { analogue } \\
\text { scale }\end{array}$ & $\begin{array}{l}\text { Oxford } \\
\text { knee } \\
\text { score }\end{array}$ & $\begin{array}{l}\text { Clinical } \\
\text { features }\end{array}$ & $\begin{array}{l}\text { Visual } \\
\text { analogue } \\
\text { scale }\end{array}$ & $\begin{array}{l}\text { Oxford } \\
\text { knee } \\
\text { score }\end{array}$ & $\begin{array}{l}\text { Clinical } \\
\text { features }\end{array}$ & $\begin{array}{l}\text { Visual } \\
\text { analogue } \\
\text { scale }\end{array}$ & $\begin{array}{l}\text { Oxford } \\
\text { knee } \\
\text { score }\end{array}$ \\
\hline $\begin{array}{l}\text { Average } \\
\text { results }\end{array}$ & 30 & 35.10 & $\begin{array}{l}\text { Pain, } \\
\text { swelling, } \\
\text { stiffness at } \\
\text { different } \\
\text { body } \\
\text { Parts/joints }\end{array}$ & 5.40 & 27.03 & $\begin{array}{l}\text { Mild } \\
\text { pain, } \\
\text { swellin } \\
\text { at } \\
\text { different } \\
\text { body } \\
\text { Parts/ } \\
\text { joints }\end{array}$ & 3.83 & 33.43 & $\begin{array}{l}\text { No any } \\
\text { complai } \\
\mathrm{n} \text { at } \\
\text { different } \\
\text { body } \\
\text { Parts/ } \\
\text { joints }\end{array}$ & 2.27 & 42.10 \\
\hline
\end{tabular}

\section{DISCUSSION}

The Oxford Knee Score (OKS) is a patient reported outcome questionnaire that was developed to specifically assess the patient's perspective of outcome following Total Knee Arthroplasty. The OKS has subsequently been validated for use in assessing other non-surgical therapies applied to those suffering from issues with the knee. ${ }^{7}$ The OKS consist of twelve questions covering function and pain associated with the knee. The benefit to this questionnaire is that it is short, practical, reliable, valid and sensitive to clinically important changes over time. ${ }^{8}$

\section{Grading for the Oxford Knee Score}

Score 0 to 19 May indicate severe knee arthritis. It is highly likely that you may well require some form of surgical intervention, contact your family physician for a consult with an Orthopaedic Surgeon.

Score 20 to 29 May indicate moderate to severe knee arthritis. See your family physician for an assessment and $\mathrm{X}$-ray. Consider a consult with an Orthopaedic Surgeon.

Score 30 to 39 May indicate mild to moderate knee arthritis. Consider seeing your family physician for an assessment and possible $\mathrm{x}$-ray. You may benefit from nonsurgical treatment, such as exercise, weight loss, and /or anti-inflammatory medication.

Score 40 to 48 May indicate satisfactory joint function. May not require any formal treatment. 
Analogue Scale (VAS) is a measurement instrument that tries to measure a characteristic or attitude that is believed to range across a continuum of values and cannot easily be directly measured. ${ }^{9}$ For example, the amount of pain that a patient feels ranges across a continuum from none to an extreme amount of pain. ${ }^{9}$

\section{VAS [Visual Analogue Scale] can be presented in a number of ways, including}

- $\quad$ Scales with a middle point, graduations or numbers (numerical rating scales),

- Meter-shaped scales (curvilinear analogue scales),

- $\quad$ "Box-scales" consisting of circles equidistant from each other (one of which the subject has to mark), and

- Scales with descriptive terms at intervals along a line (graphic rating scales or Likert scales).10 The VAS score is determined by measuring in millimetres from the left hand end of the line to the point that the patient marks.

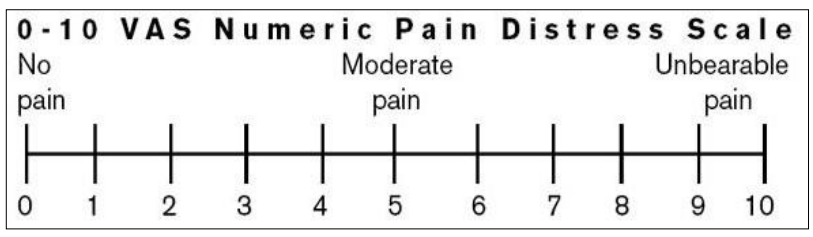

Figure 1: Example of VAS.

Avocado oil is an edible oil pressed from the fruit of the Perseaamericana (avocado). As a food oil, it is used as an ingredient in other dishes, and as a cooking oil. It is also used for lubrication and in cosmetics, where it is valued for its supposed regenerative and moisturizing properties. It is high in monounsaturated fats and vitamin $\mathrm{E}$, and also enhances the absorption of carotenoids and other nutrients. ${ }^{11}$ Avocado belongs to the flowering plant family Lauracaea. $^{12}$ Initially avocado was considered as a vegetable but later it was cleared that it's a 'pear shaped' or 'egg-shaped' fruit with dry green skin and fleshy body inside. They are mostly cultivated in tropical and temperate climates such as in California. Avocados are rich in vitamins, fibre, protein and fat content that plays important role in controlling number of ailments such as it reduces the risk of arthritis, diabetes, stroke and coronary artery disease, helps in lowering cholesterol level, promote healthy body weight and helps in preventing the development of certain types of cancer hence considered as one of the "super food". Avocado plays important role in decreasing this oxidative and inflammatory stress due to the presence of large number of xanthophyll carotenoids such as lutein and zeaxanthin which are rich in anti-oxidant properties. Extracts of avocado (300mg) was found to have significant decrease in pain and joint improvement in those suffering from osteoarthritis of knee and hip. They also have ability to decrease pro-inflammatory mediators such as interleukins, prostaglandins, reduce the production of degradative enzymes. Avocados also contain phytosterols and carotenoids, such as lutein and zeaxanthin. ${ }^{13}$ Avocado stimulates the synthesis of collagen and aggrecan by inhibiting inflammatory cytokines such as IL-1, IL-6, IL8, TNF, and PGE2 through modulation of NF-kappaB. ${ }^{14}$ In vitro studies show that Avocado oil inhibits fibrinolysis by stimulating the expression of plasminogen activator inhibitor (PAI-1). ${ }^{15}$ PAI-1 inhibits tissue plasminogen activator and urokinase (uPA), thereby blocking plasminogen activation and inhibiting fibrinolysis (the physiological breakdown of blood clots). This fibrinolytic and tissue destructive proteinase cascade may play a role in OA joint inflammation via altered expression of uPA receptors. ${ }^{16}$ Avocado acts as an anabolic agent in vitro, reducing the production of pro-inflammatory mediators, including IL-1, IL-6, IL-8, macrophage inflammatory protein-1, NO, MMP-13, TNF- $\alpha$, and COX2/PGE217. Avocado oil does not possess any side effects at therapeutic dose so safety profile of Avocado is much better than NSAIDS.

Table 4: Nutrient facts of avocado.

\begin{tabular}{|ll|}
\hline Nutrients & Per $\mathbf{1 0 0 ~} \mathrm{ml}$ \\
\hline Energy & $3350 \mathrm{~kJ}(801 \mathrm{Cal})$ \\
\hline Protein & $0 \mathrm{~g}$ \\
\hline Fat Total & $90 \mathrm{~g}$ \\
\hline$\bullet \quad$ Saturated & $13 \mathrm{~g}$ \\
\hline$\bullet \quad$ Trans fat & $0 \mathrm{~g}$ \\
\hline$\bullet \quad$ Polyunsaturated fat & $8 \mathrm{~g}$ \\
\hline$\bullet \quad$ Monounsaturated fat & $69 \mathrm{~g}$ \\
\hline Cholesterol & $0 \mathrm{mg}$ \\
\hline Total Carbohydrate & $0 \mathrm{~g}$ \\
\hline Sugars & $0 \mathrm{~g}$ \\
\hline Dietary Fiber & $0 \mathrm{~g}$ \\
\hline Sodium & $5 \mathrm{mg}(\mathrm{max})$ \\
\hline Vitamin E & $12 \mathrm{mg}$ \\
\hline Beta Sitosterol & $487 \mathrm{mg}$ \\
\hline
\end{tabular}

As the study was for a short duration a better assessment can be derived if the same study can do for a longer period of time.

\section{CONCLUSION}

Avocado has good control over pain threshold, joint stiffness and swelling. Avocado is showing better oxford knee score \& visual analogue score in comparison to NSAIDS. Avocado oil is a food supplement and does not contain any significant side effects in comparison to NSAIDS [Non-steroidal anti inflammatory drugs], glucosamine sulfate, chondroitin sulfate, sulfasalazineetc, so avocado oil can be used in long duration of treatment in case of osteoarthritis. Avocado oil can be used in place of other chondroprotective drugs like glucosamine sulfate, chondroitin sulfate, sulfasalazineetc, in the treatment of osteoarthritis. Osteoarthritis inflicts pain and physical limitation on millions of people. Improving joint function and patient activity is a central public health concern to improve quality and length of life. The aim is not only to 
treat pain but also to prevent the onset of disease. Avocado may prove to be an effective treatment option for symptomatic osteoarthritis, as they have been shown to possess chondroprotective, anabolic, and anticatabolic properties, as well as anti-inflammatory properties. At the clinical level, Avocado reduce pain and stiffness while improving joint function.

\section{Funding: No funding sources}

Conflict of interest: None declared

Ethical approval: The study was approved by the Institutional Ethics Committee

\section{REFERENCES}

1. Osteoarthritis. National Institute of Arthritis and Musculoskeletal and Skin Diseases. April 2015. Archived from the original on 18 May 2015. Retrieved 13 May 2015.

2. Glyn-Jones S, Palmer AJ, Agricola R, Price AJ, Vincent TL, Weinans H, Carr AJ. Osteoarthritis. Lancet. 2015;386 (9991):376-87. (PMID 25748615).

3. Arden N, Blanco F, Cooper C, Guermazi A, Hayashi D, Hunter D, et al. Atlas of Osteoarthritis. Springer; 2015:21. ISBN 978-1-910315-16-3. Archived from the original on 2017-09-08.

4. Flood J. The role of acetaminophen in the treatment of osteoarthritis. The American Journal of Managed Care. 16 Suppl Management (Suppl Management). March 2010:S48-54. PMID 20297877. Archived from the original on 2015-03-22.

5. Xie F, Ye H, Zhang Y, Liu X, Lei T, Li S. Extension from inpatients to outpatients: validity and reliability of the Oxford Knee Score in measuring health outcomes in patients with knee osteoarthritis. Int $\mathbf{J}$ Rheumatic Diseases. 2011 May;14(2):206-10.

6. Reips UD, Funke F. Interval-level measurement with visual analogue scales in Internet-based research: VAS Generator. Behavior research methods. 2008 Aug 1;40(3):699-704.

7. Xie F, Ye H, Zhang Y, Liu X, Lei T, LI SC. Extension from inpatients to outpatients: validity and reliability of the Oxford Knee Score in measuring health outcomes in patients with knee osteoarthritis. Int $\mathbf{J}$ Rheumatic Diseases. 2011 May;14(2):206-10.

8. Dawson J, Fitzpatrick R, Murray D, Carr A. Questionnaire on the perceptions of patients about total knee replacement. J Bone Joint Surgery. British volume. 1998 Jan;80(1):63-9.

9. Gould D. Visual Analogue Scale (VAS). J Clin Nursing. 2001;10:697-706.

10. Scott J, Huskisson EC. Graphic representation of pain. Pain. 1976;2:175-84

11. Unlu NZ, Bohn T, Clinton SK, Schwartz SJ. Carotenoid absorption from salad and salsa by humans is enhanced by the addition of avocado or avocado oil. J Nutrition. 2005 Mar 1;135(3):431-6.

12. Morton JF. Avocado; In: Fruits of Warm Climates. Creative Resource Systems, Inc., Winterville, NC and Center for New Crops \& Plant Products, Department of Horticulture and Landscape Architecture, Purdue University, West Lafayette, IN. 1987:91-102. (ISBN 0-9610184-1-0).

13. Dreher ML, Davenport AJ. Hass avocado composition and potential health effects. Critical reviews in food science and nutrition. 2013 Jan 1;53(7):738-50.

14. Mauviel A, Daireaux M, Hartmann DJ, Galera P, Loyau G, Pujol JP. Effects of unsaponifiable extracts of avocado/soy beans (PIAS) on the production of collagen by cultures of synoviocytes, articular chondrocytes and skin fibroblasts. Rev Rhum Mal Osteoartic. 1989;56(2):207-11. [PubMed].

15. Boumediene K, Felisaz N, Bogdanowicz P, Galera P, Guillou GB, Pujol JP. Avocado/soya unsaponifiables enhance the expression of transforming growth factor beta1 and beta2 in cultured articular chondrocytes. Arthritis Rheum 1999;42(1):148-56. [PubMed].

16. Belcher C, Fawthrop F, Bunning R, Doherty M. Plasminogen activators and their inhibitors in synovial fluids from normal, osteoarthritis, and rheumatoid arthritis knees. Ann Rheum Dis. 1996;55(4):230-6. [PubMed].

17. Heinecke LF, Grzanna MW, Au AY, Mochal CA, Rashmir-Raven A, Frondoza CG. Inhibition of cyclooxygenase-2 expression and prostaglandin E2 production in chondrocytes by avocado soybean unsaponifiables and epigallocatechin gallate.

Cite this article as: Chandra A, Kumar M, Kumar M, Dikshit H. Beneficial role of Avocado oil orally used in Osteoarthritis: experience in a tertiary care hospital of Bihar, India. Int J Basic Clin Pharmacol 2019;8:1167-71. 